\title{
Foreign Language Teachers' Intercultural Competence as a New Aspect of Professional Development
}

\author{
Merve Gazioğlu*1 \& Buket Güner ${ }^{1}$ \\ 1. Abdullah Gül University, The School of Foreign Languages \\ *Corresponding Author: merve.gazioglu@agu.edu.tr \\ Received : 2020-08-27 \\ Rev. Req. : 2021-01-09 \\ Accepted : 2021-03-18
}

$10.46303 / j c v e .2021 .3$

\begin{abstract}
How to cite this paper: Gazioğlu, M. \& Güner, B. (2021). Foreign Language Teachers' Intercultural Competence as a New Aspect of Professional Development. Journal of Culture and Values in Education, 4(2), 27-41. https://doi.org/10.46303/jcve.2021.3
\end{abstract}

This is an Open Access article distributed under the terms of the Creative Commons Attribution 4.0 International license (https://creativecommons.org/licenses/by/4.0/)

\begin{abstract}
This mixed-method study aims to offer an insight into foreign language teachers' perceptions on the relationship between intercultural competence and professional development. It is also attempted to explore some methods for evaluating teachers' intercultural competence through their professional development activities. The research participants are local and international instructors at a private university in Turkey. Data was collected via a web-based questionnaire and a semi-structured interview designed by the researchers. The general findings of the study indicate that learning about a) target culture, b) local culture, and c) international students' culture contribute to foreign language teachers' intercultural competence and it is considered as a part of their professional development. However, it is pointed out that pre-service and in-service teacher training programs in Turkey cannot provide sufficient facilities to develop teachers' intercultural competence.
\end{abstract}

Keywords: professional development, intercultural competence, foreign language teaching

\section{Introduction}

In today's modern world, studying abroad enables teachers and learners to experience frequent intercultural interactions in classrooms. It seems inevitable that especially foreign language teachers who are likely to practice teaching the target language to a group of learners whose native languages are different will perceive the value of intercultural competence for their professional development. Intercultural communicative competence studies have gained a great importance in the field of foreign language learning and several studies have been conducted to explore the ways to prepare learners for living in a multicultural world (Sercu, 2004). In order to facilitate students' intercultural communicative competence in educational contexts, it is essential that teachers and prospective teachers put a great emphasis on their 
own intercultural competence during their professional development. Not all foreign language teachers may get a chance to have teaching-abroad experience and to learn about international students' distinct needs, expectations, difficulties, and strengths. However, it is common for foreign language teachers to teach in heterogeneous classes in terms of culture.

Much of the research often assumes that teachers already have intercultural competence and they mainly focus on teaching culture and intercultural competence to language learners. Teachers are expected to teach intercultural communicative competence to their students but only if teachers and prospective teachers are aware of cultural differences and able to deal with such differences in their classes, they can reflect their intercultural perceptions on their teaching. Their intercultural competence representation enables them to build an intercultural competence base that will eventually influence language learners' competence. Therefore, training of culturally and linguistically diverse teachers, the inclusion of multicultural teaching perspectives in education, and the implementation of culturally responsive foreign language instruction in classroom should not be considered separate from teachers' professional development.

Compared to studies in general, there are some other ways to develop intercultural competence rather than teaching in different countries, such as reading about another culture, spending time with people from another culture, and learning about other cultures through various kinds of online ways (Deardorff, 2009). However, to what extent teachers regard such activities as a part of their professional development and how often they attempt to learn about their students' distinct cultures are seldom matters of research inquiry. This study aims to present foreign language teachers' perceptions of their intercultural competence and its relation with their professional development. By doing so, it is aimed to investigate to what extent and in what ways language teachers' intercultural competence contributes to their professional development.

Traditional work establishes "culture" as a significant component of teachers' professional development. However, it is worth noting that culture does not only refer to teaching target language culture. The main objective of culture teaching in language classes is no longer limited to the culture associated with the language or the culture of the majority in the classroom. Teachers' awareness of minority groups' different cultures and their openness and tolerance can also be listed in todays' language teachers' professional development requirements. This article has sought to provide a strong basis for the relation between teachers' professional development and their intercultural competence. We hope also to raise some general issues related to culture teaching in language classes.

Given the critical role of teachers' intercultural competence in their professional development, the following two research questions are posed:

(1) What are the foreign language teachers' perceptions of intercultural competence as a measurement of their professional development?

(2) What is the best way to measure teacher's intercultural competence through their professional development activities? 


\section{Literature Review}

The professional development of teachers is a broad area that can be studied in many different ways. Avalos (2011) states that professional development embraces teachers' ongoing learning and transforming their knowledge into practice for the sake of students' learning. Also, DiazMaggioli (2003) defines professional development as teachers' voluntary ongoing learning process focusing on its practical outcomes on students' success. Therefore, at the core of teachers' professional development, student needs and benefits are observed. There are tight links between teachers' way of teaching and students' success in learning (Diaz- Maggioli, 2004; Sparks, 2002).

Especially in the field of foreign language teaching, teachers need professional development not only to help students learn second language but also to help them develop an understanding of the target language culture (Diaz-Maggioli, 2003). Sparks (2002) argues that the scope of teachers' professional development is determined by their specific needs associated with language, pedagogy, or culture. It is clear that the previous studies have regarded teaching culture associated with the target language as a part of teachers' professional development but there is little empirical evidence of understanding students' distinct cultures.

Previous research on teachers' professional development has focused on the areas of teaching methodologies and practices (Desimone, 2009; Jimei 2002; Qiang, 2003; Yi-an, 2008). However, there are also some studies that have investigated foreign language teachers' intercultural conceptions (Byram \& Risager, 1999; Duff \& Uchida, 1997; Sercu, 2004; Sercu, 2006). Sercu (2006) notes that it is necessary to provide teachers with intercultural competence to be effective in language teaching. Byram et al. (2002) define the main components of intercultural competence as knowledge, skills, and attitudes of people toward a number of groups with different cultures and they put the main focus on the attitudes of the intercultural speaker and mediator.

On the basis of Byram's conceptual definition of intercultural competence, Sercu (2006) suggested that foreign language teachers should possess sufficient knowledge of culture associated with the foreign language they teach. However, the intercultural competence dimensions of language teachers should be extended to include teachers' own culture and learners' distinct cultures. Byram et al. (2002) states that intercultural competence does not mean knowing everything about the 'target culture'. Given this, the problem is focusing on only one 'target culture' rather than regarding every culture in a classroom. Therefore, this paper aims to discuss and draw conclusions from teachers' perceptions of how to be aware of different beliefs, values, and behaviors which international students possess. Teachers also need to regard their intercultural competence development as a part of their professional development and they should implement their intercultural perceptions into their teaching approach. The focus of this study is on the disregarded facets of teachers' professional development regarding the intercultural competence dimensions. 


\section{Method}

\section{Data Collection and Analysis}

As the first research instrument, a web-based questionnaire adapted from Sercu's survey (2006) was used to collect both qualitative and quantitative data. With the aim of exploring foreign language teachers' perceptions on their intercultural competence and professional development, both open and close questions, Likert scale, and multiple-choice questions were included in the survey. Professional development studies mostly employ qualitative data collection methods such as teacher and teaching portfolios, journals, observations, etc. However, there is no specific emphasis on the place of teachers' intercultural competence on their professional development. This data collection approach allowed us to investigate foreign language teachers' beliefs on the relationship between their intercultural competence and professional development.

The questionnaire begins with demographic questions asking participant teachers' age, gender, academic degrees, years of experience and most importantly, years of experience teaching abroad. In the following sections of the questionnaire, the various question types focused on different facets of professional development and intercultural competence. The first section aimed to raise teachers' awareness on their own teaching views, their understanding of intercultural competence and their perceptions about foreign languages and cultures. The questions in this section addressed teachers to state their priorities for professional development in terms of their familiarity with different cultures.

The next part of the questionnaire focused on the foreign language teaching asking questions about the school's international student population, teaching materials, and school organizations. The respondents needed approximately 20 minutes to complete the questionnaire. The questionnaire was offered to an opportunity sample. Approximately 50 foreign language teachers were invited to participate in the research and 20 of them responded. Each sample can be considered representative of higher education language teachers in Turkey. The responses to the questionnaire were analyzed both quantitatively and qualitatively.

The second data collection tool was a semi-structured interview developed by the researchers. It was employed to complement the quantitative data obtained by the questionnaire and it aimed to reveal teachers' perspectives on intercultural competence as a part of their professional development. Thus, eight of the Turkish teachers who answered the questionnaire were chosen purposefully and they were interviewed by the researchers for about 10-15 minutes each. After being questioned about their demographic information (years of teaching experience, years of experience abroad and academic degrees/certificates) briefly, the interviewees were asked 3 questions, all of which required extensive answers for clarification. The first question of the interview required the interviewees to rank the importance of foreign language teachers' intercultural competence as a part of their professional development. As the follow-up question, they were asked to extend and clarify their reasons to think so. The second question was about whether they have had any experience with intercultural competence raising activities as a part of their pre-service or in-service teacher training. The ones who stated the presence of this experience extended their answer giving more detail while the ones who said 'No' were asked if they consider this situation as a weakness of teacher education programs in Turkey. The last question of the interview sought to find out the best 
data collection method of professional development to learn about teachers' intercultural competence development. Eleven methods including workshops, teacher portfolios, classroom observation and so on were ordered from 1 to 11 by the interviewees, who were all knowledgeable about these methods. Then, they explained their reasons of ranking again. Hereby, the interview stage of the data collection process attempted to create a stronger link between professional development and foreign language teachers' intercultural competence by eliciting their ideas on these two notions. The answers were analyzed both quantitatively and qualitatively.

\section{Participants}

20 foreign language teachers in total contributed to this study during both the questionnaire stage and interview stage. To start with the questionnaire respondents who consist of 13 female (65\%) and 7 male (35\%) teachers, their ages ranged from 25 to 50 and over. However, the majority (40\%) of them were between 25 and 29 years old. Turkish instructors predominated $(75 \%)$ to American teachers (15\%) and foreign teachers (10\%) from other countries. Fifty percent of the teachers could speak Turkish and English while twenty-five percent of the teachers could speak only English. The other twenty-five percent of the teachers stated that they could speak foreign languages including French, Spanish, German, Indonesian, Polish, Italian, and Hebrew.

As for the academic degrees, the $65 \%$ of the participants had Bachelor's Degree while the others had MA (30\%) or other certificates (5\%). Years of experience in teaching varied from 2 years to 25 years and over. Yet, the majority of the teachers (60\%) had an experience of 10 years at most. Finally, as for the years of experience in teaching abroad, 12 teachers (60\%) stated that they had no such experience while 8 teachers had experience on teaching abroad which ranged from 9 months to 25 years

\section{Results}

\section{Findings from the Questionnaire}

The first section of the web-based questionnaire (adapted from Sercu, 2006), which aimed to understand the teachers' attitudes towards their students and teaching in terms of intercultural competence through five statements, yielded the following results:

Table 1. Teachers' attitudes in terms of cultural differences

\begin{tabular}{ll}
\hline As a teacher, I try to... & Frequency \\
\hline treat all my students equally & 5 \\
take their differences into consideration & 15 \\
raise awareness for cultural differences in my class & 17 \\
disregard cultural differences among my students & 3 \\
pay more attention to students who are trying to adapt to a new culture focus & 13 \\
on my teaching instead of dealing with the cultural differences & 7 \\
employ humors, jokes etc. in my class to create a friendly environment & 17 \\
avoid misunderstandings caused by cultural differences & 3 \\
use textbooks and materials that address to students from different cultures & 8 \\
focus on the aspects that are related to the target culture as much as possible & 12 \\
\hline
\end{tabular}


In the second part, the respondents were asked to range nine statements from 1 to 5 (1=the strongest opinion, 5 =the weakest opinion) according to their understanding by "intercultural competence" in a foreign language teaching context. Thus, we got the following average scores from their responses

Table 2. Teachers' ranking of the meaning of "intercultural competence"

\begin{tabular}{lll}
\hline Ranking & Statement & $\begin{array}{l}\text { Number of people } \\
\text { scoring "1" }\end{array}$ \\
\hline 1 & $\begin{array}{l}\text { To develop attitudes of openness and tolerance towards } \\
\text { other peoples and cultures }\end{array}$ & 14 \\
2 & $\begin{array}{l}\text { To promote the ability to empathize with people living in } \\
\text { other cultures }\end{array}$ & 10 \\
3 & $\begin{array}{l}\text { To promote reflection on cultural differences } \\
\text { To promote increased understanding of students' own }\end{array}$ & 8 \\
4 & $\begin{array}{l}\text { culture } \\
\text { To promote the ability to handle intercultural contact }\end{array}$ & 8 \\
5 & $\begin{array}{l}\text { Situations } \\
\text { To provide information about shared values and beliefs }\end{array}$ & 6 \\
7 & $\begin{array}{l}\text { To provide information about the history, geography and } \\
\text { political conditions of the foreign culture(s) }\end{array}$ & 5 \\
\hline $\begin{array}{l}\text { To provide information about daily life and routines } \\
\text { To provide experiences with a rich variety of cultural } \\
9\end{array}$ & 5 \\
\hline
\end{tabular}

The third section in the questionnaire had 7 questions related to their perceptions about foreign languages and cultures. The first question presented statements related to teachers' perceptions about their own competences on cultures in the form of a Likert scale (totally agree, agree, neutral, disagree, totally disagree). Here are the answers given by the teachers:

Table 3. Teachers' perceptions on their cultural competences

\begin{tabular}{|c|c|c|c|c|c|}
\hline \multirow[t]{2}{*}{ Statement } & \multicolumn{5}{|c|}{ Agreement Level \& Number of People } \\
\hline & $T A$ & $A$ & $N$ & $D$ & $T D$ \\
\hline $\begin{array}{l}\text { I have sufficient knowledge and experience about } \\
\text { my own culture. }\end{array}$ & 9 & 10 & 1 & - & - \\
\hline $\begin{array}{l}\text { I have sufficient knowledge and experience about } \\
\text { the culture of target language. }\end{array}$ & 4 & 10 & 3 & 3 & - \\
\hline $\begin{array}{l}\text { I have sufficient knowledge and experience about } \\
\text { my international students' culture. }\end{array}$ & 1 & 3 & 7 & 7 & 2 \\
\hline
\end{tabular}


In the same section, the second question asked "Which one do you think is more important for your professional development as a foreign language teacher?" and required the respondents to choose one of the three options. Thus, eleven teachers (55\%) stated that their familiarity with the cultures associated with the foreign language they teach was more important than the others. Six teachers (30\%) thought that their familiarity with the cultures associated with the students they teach was more important while three teachers $(15 \%)$ regarded that their familiarity with the culture associated with the majority group was more important.

As an extension to this question, they wrote about their reasons to choose the related option. Most of the teachers expressed that they are all important and interwoven. The majority of the teachers' regarded the target culture as more important and their reasons included the issues of practicality, being task-oriented, usefulness and meeting the students' needs about the target culture. Besides, they stated that appealing to different cultures was time-consuming - even impossible. Moreover, one teacher stated that the language usage depends upon the culture of that language - not on the culture of the learner. The teachers who thought that their familiarity with the cultures associated with the students they teach was more important suggested some reasons such as doing their job easily in this way and being more helpful to the students. One of the teachers stated that using the students' culture as scaffolding promotes acquisition of the L2. Finally, the ones who thought that being familiar with the culture associated with the majority group was important noted that being able to respond to the culture-related needs of students in general helps them to teach in a sufficient way.

The third question was about the teachers' familiarity with the foreign cultures in their classes and $50 \%$ of the respondents stated that they were not sufficiently familiar while $45 \%$ claimed that they were sufficiently familiar with them. Only one person asserted that he/she was very familiar with the foreign cultures in his/her class while no one thought that they were not familiar at all. For the next question in this section, "Have you ever searched about the foreign cultures primarily associated with the international students in your classes?", half of the respondents said "Yes" and the other half said "No". The ones who said "Yes" chose a frequency in terms of trying to learn about their international students' culture. Thus, only $23 \%$ of the respondents chose "often" while 38,5\% and the other $38,5 \%$ of teachers answered this question as "rarely" and "once in a while".

The fifth question, which was totally qualitative, aimed at revealing the reasons to regard being familiar with the students' home culture as necessary or not. Nearly all of the respondents agreed that it was very important. The most common point in their answers was that it would help avoiding cultural misunderstandings. Another frequent reason was about its effect on the teacher-student relationships. They also thought that knowing about taboos in a culture and respecting cultural differences are vital in a language classroom.

The sixth question, "How often do you get into contact with the foreign cultures that are primarily associated with your international students outside of the class?" offered some activities in the form of Likert scale and they marked a frequency for each activity (often, once in a while, rarely, never). Here are the results for this question: 
Table 4. Teachers' contact with the foreign cultures outside of the class

\begin{tabular}{|c|c|c|c|c|}
\hline \multirow[t]{2}{*}{ Activity } & \multicolumn{4}{|c|}{ Frequency \& Number of People } \\
\hline & often & once in a while & rarely & never \\
\hline Travelling to the foreign countries & 1 & 5 & 10 & 4 \\
\hline Watching international TV channels & 1 & 14 & 4 & 1 \\
\hline $\begin{array}{l}\text { Listening to radio stations originating in various } \\
\text { countries }\end{array}$ & 1 & 5 & 8 & 6 \\
\hline $\begin{array}{l}\text { Reading newspapers or magazines including } \\
\text { different cultures }\end{array}$ & 2 & 9 & 9 & - \\
\hline $\begin{array}{l}\text { Reading literature written by authors living in or } \\
\text { originating from foreign countries }\end{array}$ & 3 & 7 & 7 & 3 \\
\hline $\begin{array}{l}\text { Using the internet to learn more about the } \\
\text { foreign countries/cultures }\end{array}$ & 9 & 9 & 2 & - \\
\hline
\end{tabular}

Similarly, the last question of this section attempted to find out the extent that the teachers deal with particular cultural aspects primarily associated with their international students:

Table 5. Dealing with particular cultural aspects

\begin{tabular}{lllll}
\hline Cultural aspect & \multicolumn{4}{l}{ Frequency \& Number of People } \\
& often & once in a while & rarely & never \\
\hline $\begin{array}{l}\text { Daily life and routines, living conditions, food } \\
\text { and drink etc. }\end{array}$ & & 5 & 6 & - \\
Traditions, folklore, tourist attractions & 7 & 8 & 5 & - \\
Values and beliefs & 6 & 6 & 8 & - \\
Professional life, education & 4 & 8 & 7 & 1 \\
Other cultural expressions (music, drama, art) & 3 & 8 & 8 & 1 \\
Different ethnic and social groups & 1 & 9 & 9 & 1 \\
History, geography, political system, religion & 1 & 8 & 8 & 3 \\
Youth culture & 1 & 8 & 8 & 3 \\
International relations (political, economic and & 1 & 8 & 7 & 4 \\
cultural) with students' own country and other & & & & \\
Literature & 1 & 6 & 8 & 5 \\
\hline
\end{tabular}

The last section of the questionnaire contained questions about teachers' foreign language teaching contexts in relation to intercultural competence. It started with asking the percentage of international students at their school contexts. Half of the respondents indicated that it was around $10 \%-30 \%$ while $45 \%$ of the teachers gave a percentage of 1-10. Only one teacher stated that this population was less than $1 \%$.

The second question was about teaching materials: "Do you use textbooks and/or additional teaching materials that include other cultures rather than foreign language culture you teach?" $65 \%$ of the teachers declared that they use such materials and $35 \%$ of the teachers stated that 
they do not. The next question, which was related to the previous one, aimed to find out whether the cultural contents of the materials they use meet their expectations or not. Although they were given four scales, the teachers chose neither the option "Yes, very much so." nor the option "No, not at all." So, $85 \%$ of the participants claimed that the cultural contents of the materials meet their expectations up to a certain extent while $15 \%$ of the teachers asserted that they do not really meet their expectations. However, when they were also asked to explain why they think so, their ideas were mostly negative about the cultural content of the materials. The majority of the teachers complained that the materials they use generally focus on the culture of target language. Some of them explained that they use some extra materials to meet their students' cultural needs. Some teachers also claimed that the cultural content of the books do not appeal to their students so they need to be enriched in a way which will address to students from different cultures. They also stated that it was simplistic, limited, idealistic and not neutral.

The fourth question of this part was related to the cultural activities in their teaching contexts: "Does your school organize (cross-curricular) intercultural/ multicultural / international activities?" $70 \%$ of the teachers expressed that their institutions organize such activities while $30 \%$ stated that they do not have such activities in their schools. The ones who responded positively were asked to elaborate on their answers by giving specific examples. They listed some special occasions like African Day, Nevruz, kermes, and other organizations prepared by international students' offices. However, some of the respondents also mentioned that these events are not sufficient to raise intercultural awareness. Answering the follow-up question, they all agreed that these activities have a positive effect on the attitudes and perceptions of both pupils and foreign language teachers regarding foreign countries, foreign cultures, and foreign people. While giving reasons for their opinions, most of the respondents looked at the topic only from the students' perspective. They expressed that being exposed to different cultures and traditions unifies the students and raises awareness for different cultures in addition to teaching the students to respect cultural values and overcome prejudices. They also asserted that such kind of activities make education more fun and efficient besides making the students interested in the languages. Yet, a few teachers hold the belief that local students are not so interested in these activities and especially when they are a part of the materials as cultural content, they are not interested at all. Thus, they think more events should be organized to get the local and intercultural students come closer.

The last question of the questionnaire included 15 statements concerning intercultural foreign language teaching. It required the participants to score a number of statements on a 5-pointscale, ranging from 'I agree completely' to 'I do not agree at all'. Table 6 summarizes their answers according to the most and the least agreed statements: 
Table 6. Teachers' perceptions on intercultural competence and foreign language teaching

\begin{tabular}{|c|c|c|}
\hline Statement & $\begin{array}{l}\text { 'I agree } \\
\text { completely' }\end{array}$ & $\begin{array}{l}\text { 'I do not } \\
\text { agree at all' }\end{array}$ \\
\hline $\begin{array}{l}\text { Foreign language teaching should not only touch upon foreign } \\
\text { cultures. It should also deepen pupils' understanding of their own } \\
\text { culture. }\end{array}$ & 16 & - \\
\hline $\begin{array}{l}\text { A foreign language teacher should present a positive image of } \\
\text { different foreign cultures and societies. }\end{array}$ & 14 & - \\
\hline $\begin{array}{l}\text { The more teachers know about the foreign cultures in their } \\
\text { classes, the more tolerant they are towards their international } \\
\text { students. }\end{array}$ & 13 & - \\
\hline $\begin{array}{l}\text { In international contacts misunderstandings arise equally often } \\
\text { from linguistic as from cultural differences. }\end{array}$ & 9 & - \\
\hline $\begin{array}{l}\text { Every subject, not just foreign language teaching, should promote } \\
\text { the acquisition of intercultural skills. }\end{array}$ & 9 & - \\
\hline $\begin{array}{l}\text { I would like to promote the acquisition of intercultural skills } \\
\text { through my teaching. }\end{array}$ & 8 & - \\
\hline $\begin{array}{l}\text { Foreign language teachers should be trained to enhance their } \\
\text { communication with pupils with ethnic minority. }\end{array}$ & 6 & - \\
\hline $\begin{array}{l}\text { I would like to teach intercultural competence through my foreign } \\
\text { language teaching. }\end{array}$ & 5 & - \\
\hline Intercultural education is best undertaken cross-curricularly. & 4 & - \\
\hline $\begin{array}{l}\text { It is impossible to be aware of and open to all different cultures in } \\
\text { foreign language classes. }\end{array}$ & 3 & 4 \\
\hline $\begin{array}{l}\text { Intercultural skills of teachers cannot be acquired at pre-service or } \\
\text { in-service training. }\end{array}$ & 2 & 1 \\
\hline $\begin{array}{l}\text { Intercultural education reinforces pupils' already existing } \\
\text { stereotypes of other peoples and cultures. }\end{array}$ & 1 & 7 \\
\hline $\begin{array}{l}\text { Intercultural competence of teachers has no effect on their } \\
\text { teaching. }\end{array}$ & - & 11 \\
\hline $\begin{array}{l}\text { Only if there are ethnic minority community pupils in your classes, } \\
\text { you have to teach intercultural competence. }\end{array}$ & - & 8 \\
\hline $\begin{array}{l}\text { I think teaching intercultural competence only includes teaching } \\
\text { target language culture. }\end{array}$ & - & 8 \\
\hline
\end{tabular}

\section{Findings from the Interview}

This semi-structured interview helped the researchers gain insights about foreign language teachers' perceptions on the relationship between intercultural competence and professional development. To start with the demographics, the years of experience of the interviewees ranged from 5 to 17. Only one of the teachers had 1-year experience abroad while the rest did not have such experience. Half of the participants had their MA degrees while the other half had their Bachelor's Degree only. 
Answering the first question, 5 out of 8 teachers stated that foreign language teachers' intercultural competence is very important for their professional development and the other 3 thought that it was important, too. The reasons given by the interviewees suggested that intercultural competence should be a part of foreign language teachers' professional development for some reasons. The most frequently mentioned reason is that the students' needs are changing in this globalized, multicultural world so are the competencies owned by the teachers. They stated that this competence is especially crucial if the teachers have students or colleagues with various cultural backgrounds. Some of the teachers regarded intercultural competence as a way of dealing with problems caused by cultural differences in the class so they described it as a "must". They also made a connection between intercultural competence and establishing effective relationships with students, which will lead to a better language education according to them. Two of the teachers asserted that interculturally competent teachers have a role in enhancing the students' language competence as well.

The second question that was about the interviewees' experiences on intercultural competence activities during their pre-service and in-service teacher training yielded a notable result. All of the eight teachers stated that they have never experienced such activities neither their pre-service nor in-service teacher training years. Therefore, they expressed that it is a big deficiency in Turkey in terms of teacher education so more emphasis should be given to intercultural competence raising activities and related courses in teacher education programs. One of the teachers drew an analogy between being a foreign language teacher and being a tailor - saying, "A teacher without intercultural competence is like a tailor without his/her scissors, nails and thread". Eventually, they concluded that being exposed to intercultural competence raising activities improves the teachers' effectiveness in teaching by changing their perspectives about different cultures and languages.

The last question of the interview asked the interviewees to put the given data collection methods of professional development in order to determine the best one. The first figure below shows the top three methods and the second figure shows the methods that were placed to the last priorities by the teachers:

Figure 1. 'The best' PD methods for ICC

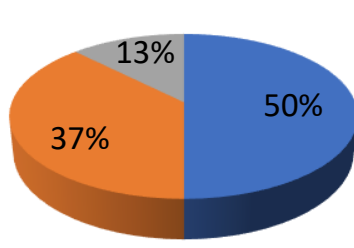

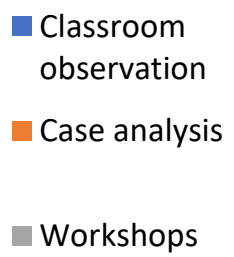

Figure 2. 'The worst' PD methods for ICC

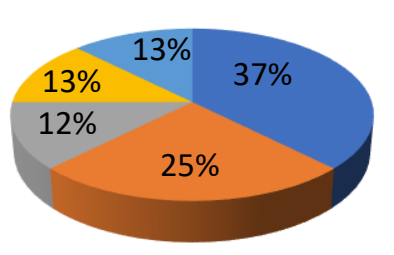

Workshops

- Team teaching

Self-monitoring

Peer-coaching

Action Research

The interviewees were also requested to elaborate on their reasons of ranking. The ones who opted for classroom observation method as the most effective way of collecting data to measure foreign language teachers' intercultural competence gave similar reasons. They stated 
that seeing what is really happening in class is the best way as it provides objective, profound, and first-hand data to gain insights on this issue. The teachers who chose case analysis as the most effective method thought that it gives deeper understanding especially to overcome problems related to misunderstandings stemming from cultural differences.

Some interviewees also provided reasons for choosing workshops, self-monitoring, or team teaching as the least effective methods. They explained that attending to workshops is a passive process and it is generally useless when the gained knowledge is not put into practice. One of the teachers even said "Workshops are to get training, not to gauge the development!". Another teacher stated that self-monitoring is not effective because "reflecting only on your own context and teaching may not be enough to develop your intercultural competence". As a result, the majority of the teachers that were interviewed had similar ideas about the place of intercultural competence in foreign language teachers' professional development.

\section{Discussion and Conclusion}

This study has explored foreign language teachers' perceptions on the role of intercultural competence in their professional development. On the contrary to the previous research scope generally focusing on "how to teach target culture to students", it was aimed at illustrating the effect of teacher's own culture on his/her teaching, in connection with his/her professional development. Moreover, it was shown that improving intercultural competent is a new and essential aspect of foreign language teachers' professional development.

The general findings from this study revealed that foreign language teachers regard intercultural competence as a part of their professional development. As put by one of the teachers, "Language is a reflection of culture" so teaching a language should respond to students' cultural needs as well. Despite they tend to focus more on teaching the target culture in terms of materials, most of the teachers attempt to raise awareness for cultural diversities in their classroom contexts by taking differences into account. It shows that teachers guide their students to be "world-citizens" in this globalized world that does not need boundaries of language and culture any more. Moreover, they consider intercultural competence as a way of promoting empathy towards people from various cultural backgrounds. According to them, intercultural competence for professional development means developing attitudes of openness and tolerance for different cultures rather than learning about abstract topics like history, geography or politics related to that culture. Therefore, foreign language teachers should support creating environments that will enable the students to experience multiculturalism and to develop positive attitudes toward it.

As another important aspect of intercultural competence, teachers believe that they have sufficient knowledge and experience about their own culture and the culture of target language. However, they do not have enough information and experience about their international students' cultures, which may cause some misunderstandings and communication problems. Thus, interacting with international people and being exposed to different cultures appear to be the primary need for both pre-service and in-service foreign language teachers. The effect of this deficiency can be seen through teachers' perceptions about being familiar with different cultures for their professional development. The majority of teachers regard being able to cover the culture of target language (English) during teaching as more important than being able to address to the students' own culture because they think it is more practical and useful 
in language teaching. However, they seem to undermine the concept of ELF, which requires students to learn how to negotiate with people from various cultures using English.

Similarly, most of the teachers regard themselves as being unfamiliar with their international students' culture and even if some of them claim that they are familiar, they reflect the gap between theory and practice. In other words, the majority of the teachers do not have sufficient attempts to learn about different cultures and implementing their gains in their professions. Yet, they agree on the importance of being familiar with their students' home culture by regarding it as a way of avoiding misunderstandings in addition to building constructive teacher-student relationships. Hence, it can be said that foreign language teachers appreciate friendly and diverse classroom settings as they promote language learning.

The participant foreign language teachers in the present study mostly rely on technology to get into contact with foreign cultures of their international students. They have limited chance to socialize face-to-face with minority culture groups outside of the class as the living environment is nearly homogenous in terms of culture. However, the study revealed that even if there are no international students in a class, it is a necessity for foreign language teachers to have intercultural competence. We may relate this finding with "No Child Left Behind Act", a law passed by U.S. Act of Congress (2002). This view aims to equalize the opportunities and facilities of every single student regardless of their socio-economic, language, and cultural distinctions. Therefore, minority and majority distinctions lose its influence on education.

The data revealed that approximately 5 to $15 \%$ of the school population contains international students. Although it is not an outstanding number, all of the participants of the study acknowledge the place of intercultural competence in their professional development. It was also found that the participant foreign language teachers' understanding of 'intercultural competence' does not include the knowledge of daily life routines of international students. Yet, when they were asked to indicate to what extent they deal with cultural aspects associated with international students, a great deal of them stated that they mostly deal with the daily routines and traditions of those international students. Therefore, we can conclude that getting information about international students' daily life is not the main purpose of the language teachers in terms of their intercultural competence development but it is only a way to make them aware, open and more tolerant to cultural differences. That is to say, getting enough knowledge associated with international students' culture is a process that leads teachers toward being interculturally competent. On the other hand, the content of this grounding process does only include very general points of that culture such as daily routines, music, movies, traditions, etc. rather than specific details such literature, politics, and economics. This finding may also result from the content of commonly used teaching materials, which focus on social life. In addition, the participant teachers stated that, in a way, they integrate different cultures rather than the target language culture in their teachings especially using additional materials because as some of the teachers noted, cultural contents of the textbooks do not meet their expectations. The data also put light upon the positive influence of organizing multicultural activities on both the national and international students but as this aspect cannot be associated with teachers' professional development, it was not given a special emphasis. 
Another point that was revealed by the data is the importance of foreign language teachers' and language learners' understanding of their own culture. Awareness and understanding of cultures are not limited into the majority and minority groups in the classrooms or the target language culture. Rather, foreign language teachers should be trained about the integrity and sophistication. By doing so, language classes can be regarded as a melting pot where there is empathy, understanding, awareness, and openness. For this reason, the present study holds this aim of regarding intercultural competence as a part of teachers' professional development. However, none of the interview respondents of the present study was exposed to intercultural competence training as a part of their professional development. The data findings reveal the gap in both teachers' pre-service training and also in-service training. The respondents of the interview also regard this gap as a deficiency in their professional development.

\section{References}

Avalos, B. (2011). Teacher professional development in Teaching and Teacher Education over ten years. Teaching and teacher education, 27(1), 10-20. https://doi.org/10.1016/j.tate.2010.08.007

Byram, M., Gribkova, B., \& Starkey, H. (2002). Developing the intercultural dimension in language teaching. Strasbourg: Council of Europe, 41.

Byram, M., \& Risager, K. (1999). Language teachers, politics and cultures. Multilingual matters.

Deardorff, D. K. (2009). Implementing intercultural competence assessment. The SAGE handbook of intercultural competence, 477-491.

Desimone, L. M. (2009). Improving impact studies of teachers' professional development: Toward better conceptualizations and measures. Educational researcher, 38(3), 181199.

Diaz-Maggioli, G. (2004). A passion for learning: Teacher-centered professional development. Alexandria, VA: Association for Supervision and Curriculum Development.

Diaz-Maggioli, G. H. (2003). Professional development for language teachers. ERIC Digest No. EDOFL-03-03. Retrieved November 12, 2016, from http://www.cal.org/resources/digest/0303diaz.html

Duff, P. A., \& Uchida, Y. (1997). The negotiation of teachers' sociocultural identities and practices in postsecondary EFL classrooms. Tesol Quarterly, 31(3), 451-486.

Jimei, X. (2002). A report on investigating the College English teachers' knowledge of and beliefs in foreign language education and their roles in teaching, researching and professional development [J]. Foreign Language World, 5.

Qiang, G. X. W. (2003). Reflective Teaching: an Effective Approach to Enhancing EFL Teachers' Professional Development [J]. Foreign Language Education, 2.

Sercu, L. (2004). Assessing Intercultural Competence: A Framework for Systematic Test Development in Foreign Language Education and Beyond. Intercultural Education, 15(1), 73-89.

Sercu, L. (2006). The foreign language and intercultural competence teacher: The acquisition of a new professional identity. Intercultural education, 17(1), 55-72. 
Sparks, D. (2002). Designing powerful staff development for teachers and principals. Oxford, $\mathrm{OH}$ : National Staff Development Council.

Yi-an, W. U. (2008). A Study of Effective EFL Teachers' Professional Development [J]. Foreign Languages Research, 3. 